\title{
Analysis of Libles Obscuur in Civil Suits in Medan State Court
}

\section{Danial Syah}

Universitas Islam Sumatera Utara

Email : sh.mhdanialsyah@yahoo.com

\begin{abstract}
.
The research study about first to find out the reasons for the judge declaring a lawsuit unclear or obscure (obscuur libel) and second is to find out the consequences of an unclear or obscure lawsuit (obscuur libel). In this study using qualitative data analysis. The approach method in this research is to use a normative juridical approach, namely an approach that is carried out by collecting secondary data.The results of this study were (1) The reason the judge stated that a lawsuit was unclear or obscure (obscuur libel) were nine factors that caused the claim submitted by the plaintiff to be unacceptable. The nine factors are: (a) The identity of the parties (Plaintiff and Defendant). (b) The object of the lawsuit being litigated is unclear. (c) Petitum lawsuit exceeds the claim posita. (d) Power of attorney does not meet the requirements. (e) The lawsuit is filed by an underage / incapable person. (f) Claims are not filed on time. (g) Incomplete parties. (h) The court is not competent to hear the claim that is submitted. (i) The grounds of the plaintiff's rights are not clear. (2) As a result of a lawsuit is unclear or obscure (obscuur libel), then the person concerned does not accept such a decision, because the decision does not give satisfaction to what he wants from the claim as stated in the lawsuit. Because the verdict cannot be accepted in practice in the District Court based on the consideration that the plaintiff's claim is unacceptable, in fact it is a consideration regarding the subject matter of the case, namely whether the plaintiff is the owner or entitled to the suspect land, it is more appropriate to declare the claim rejected. Therefore, the plaintiff's unclear rights to the object of the lawsuit in dispute are not appropriate to be used as legal considerations to declare the claim unacceptable.
\end{abstract}

Keywords: Obscure Libel, Lawsuit, Civil, Medan District Court

\section{INTRODUCTION}

Civil suits are an important issue especially for those who want a case settlement through the Court. In fact, in practice, there are many claims submitted to the Court which are declared unacceptable because the lawsuit does not meet the desired conditions, namely the formal requirements of the lawsuit.

The formalities of the lawsuit include unclear identity of the parties (plaintiff and defendant), incorrect name or address of the defendant is incomplete, the lawsuit is vague, the object of the lawsuit is unclear, the petitum of the lawsuit exceeds the posita of the lawsuit, the power of attorney does not meet conditions, the lawsuit is brought forward by an immature or incapable person.

The process of drafting a lawsuit plays a very important role, considering that if the lawsuit is unclear or vague which is often referred to as obscuur libel, then the lawsuit will not be granted by the judge. Thus the obscure or obscure lawsuit (obscuur libel) means the lawsuit that is submitted by the plaintiff and after going through the examination stage by the judge, then the judge concerned decides that this lawsuit cannot be accepted because it does not fulfill one or more of the formal requirements of the lawsuit. So the judge declared that the lawsuit was unacceptable not because the material being challenged was not proven, but only because the formal requirements were not fulfilled, for example the identities of the defendants were incomplete, the lawsuit was filed prematurely, the lawsuit was submitted to a court that is not authorized to examine the lawsuit. and so forth. If because the plaintiff cannot prove the material of his lawsuit, then the claim is declared by the 
judge to be rejected and not unacceptable. Due to the law that will arise from an unclear or obscure lawsuit (obscuur libel) against the plaintiff, the plaintiff can file a new lawsuit again. This does not make the new lawsuit a Nebis in idem, because the obscure or obscure lawsuit (obscuur libel) is due to a lack of formality in the lawsuit.

\section{METHODS}

The research specification is descriptive research, namely by describing a situation or a phenomenon related to the problem to be studied. [1] The approach method in this research is to use a normative juridical approach, namely an approach that is carried out by collecting secondary data [1] in the form of legislation and materials relevant to the problems in this study. Data analysis in this study used qualitative data analysis.

\section{RESULT AND DISCUSSION}

\section{A. Reasons for the Judge to Declare a Lawsuit Are Unclear or Obscure (Obscuur Libel)}

an obscure or obscure lawsuit (obscuur libel) is declared rejected and accepted will bring up two attitudes from the litigant, namely: accept or reject. K. Wantjik stated as follows: The first attitude is an attitude that accepts the verdict while the second is that the plaintiff and / or the defendant can file an appeal, it means the attitude that rejects the verdict. Both of these attitudes can also occur in high court decisions. The plaintiff and / or defendant accept the verdict and therefore the winning party can request the implementation of the high court decision and if the plaintiff and / or defendant does not accept the judge's decision, he can submit an appeal to the Supreme Court of the Republic of Indonesia. [2]

HIR and R. bg said that there is nothing specifically that regulates the obscure or obscure lawsuit (obscuur libel) but in daily practice there are several things that cause the lawsuit to be declared (NietOnvankelijkverklaard). Abdul Manan said that a lawsuit could not be accepted or NietOnvankelijkVerklaart (N.O), which means that the lawsuit cannot be accepted, namely the court decision submitted by the Plaintiff cannot be accepted, because there are reasons justified by law. [3] The reasons for the lawsuit are unclear or obscure (obscuur libel) so that the lawsuit cannot be accepted there are several possibilities as follows: (a) The lawsuit is not based on law. (b) Improper claim. (c) The lawsuit is contrary to decency / public order. (d) Wrong claim. (e) Obscure lawsuit. (f) The lawsuit does not meet the requirements. (g) The object of the lawsuit is not clear. (h) The subject of the lawsuit is incomplete. (i) And others. [4]. There are nine factors that cause the lawsuit submitted by the plaintiff to be unclear or obscure (obscuur libel) so that the lawsuit cannot be accepted, namely:

1. The identity of the parties (Plaintiff and Defendant is not clear).

Part of the lawsuit concerns the identities of the plaintiffs and defendants, namely: Name, Age, Occupation, Address and so on.The identity of the parties must be clear, because if the identity is not clear then there will be several consequences arising from it, among others: (a) Concerning the authority to judge. (b) Regarding the legal relationship between the parties and the subject matter.

This issue of authority to judge will arise especially if the address of the defendant is incorrect. For example, A wants to sue B who lives in Binjai to the Medan District Court, while the object of the lawsuit is regarding accounts payable. In such a case, the plaintiff's claim cannot be accepted because the authority to try the case is the Binjai court.

On the other hand, it could be that the plaintiff's identity is wrong, for example the one who should sue is (as a child), because according to B's opinion, his child's right is also his right as a father. If these identities are found, this can result in the plaintiff's claim being unacceptable (NO). 
2. The object of the lawsuit being litigated is not clear

The object of the claim is what is / is being disputed. Here, for example, if a case is related to land, the object of the case is the disputed land, in other matters we can also take an example, for example: Cases of Accounts Receivable, then the object of the case is money and so on.

The object of the lawsuit in the case must be clear, because if the object is not clear, it will make it difficult to implement the judge's decision if the plaintiff's claim is granted by the judge, for example A sues B so that B returns A's land which has been in control for decades, but in the lawsuit it is not stated where it is. actually the land that B will return. If A's claim is granted by the Judge, the decision will be difficult to enforce, because it is not known which land B must return to A. So if the object of the lawsuit is not clear, it will result in the claim by the Judge being declared unacceptable. In daily practice, the unclear object of a lawsuit is often the object of the defendant's exception.

3. Petitut Lawsuit Exceeds Posita Lawsuit.

As stated in the previous section when discussing the form of a lawsuit, two parts of which are about the Positia and Petitum. In civil procedural law it is not regulated how the relationship between posita and petitum is, but in daily practice it has become a legal custom that between posita and petitum there must be a close relationship. There must be a reciprocal relationship. It is said thus, because there is a principle which states: things that are requested in a petitutm must be stated in a posita, but things that are stated in a posita do not have to be requested in a petitum.

4. Power of Attorney does not meet the requirements.

Civil procedural law is known as a principle of not having to be represented for litigation. However, it is also not forbidden to be represented by other people as proxies. [5] Most people in a case are represented by other people as proxies to manage their interests at every level of examination (District Court, High Court, Supreme Court). From this fact it is clear that proceedings before the Court can be carried out indirectly by the interested parties and vice versa can also be carried out directly. If proceeding indirectly, the parties in the case will represent their interests to another person, namely those who are called the recipient of power. Representing this case is regulated in Article 123 HIR / 147 R.bg. This article states:

a) If desired, the two parties may be assisted or represented by a power of attorney, which he powers if the person giving the power of attorney is not present alone, the person who accuses the party can also authorize that in the letter of request signed by him and entered according to paragraph (1) Article 118 or the demands made in this way are mentioned in the notes made regarding the demands.

b) Civil servants who, due to the general regulation, carry out cases for the government as representatives of the country, do not need to use this special power of attorney.

c) The District Court has the power to give orders so that both parties, represented by their proxies at the trial, come before themselves.

d) The power does not apply to the Governor General. [6]

5. The lawsuit was filed by an underage / incapable person.

In principle, every person who feels he has rights and wants to sue or defend his rights is authorized to act as a party in a case, both as plaintiff and as defendant (legima peson standiim judicio). The ability to act legally is an important and also a legal issue. There is one principle, who is able to act is also considered capable of acting as a party before the court. People who are considered incapable are minors or people who are under forgiveness. According to the Civil Code, the maturity limit for a person is 21 years, article 330. For Indigenous Indonesians, it is determined in STb. 1931 No. 54. In this Stb it is determined, if the provisions of the law use the term not yet old enough, then the Indonesian group in question is not yet 21 years old or has been previously married. Therefore, in essence, we are guided by article 330 of the Civil Code. 
Generally, those who are placed under pardon cannot proceed with proceedings and act as parties before the Court of Article 446, 452 of the Civil Code, especially for those who are placed under pardon because of mental illness. As for the extravagant and drunkard, this inability is limited to actions in the field of wealth. If it turns out that the people as mentioned above have filed and signed the lawsuit, then the lawsuit will be declared unacceptable. One example of a lawsuit declared unacceptable because the plaintiff was immature was as decided by the Supreme Court of the Republic of Indonesia with decision No. 1155 / K / Sip / 1981 dated 31 October 1981.

6. The lawsuit was not filed on time.

As has been stated in the previous section, the plaintiff's submission of a lawsuit is to defend his rights / interests which have been violated by others. Thus the lawsuit should arise when the interests of the plaintiff have been disturbed by other people. Therefore, if it is put forward before the interests of the plaintiff are disturbed, then the claim cannot be accepted (NO).

7. The parties are not complete

One case consists of at least two parties, namely the Plaintiff and the Defendant. In a simple case the parties consist of a plaintiff and a defendant. However, it is not uncommon for the plaintiff to consist of more than one defendant against one defendant, or conversely one plaintiff against more than one defendant. This is known as subjective cumulation, the amalgamation of subjects. Subjective cumulation occurs for example when a creditor transfers several debtors or several heirs to sue other heirs regarding the inheritance.

8. The court is not authorized to hear the claim that is submitted.

Regarding the authority to judge by the Judge (Court Competence), there are several differences of opinion. The difference of opinion is around the question: whether the decision is not authorized by the court to examine a case, including the verdict (NietOnvankelijkverklaard) or not.

9. The grounds of the plaintiff's rights are not clear

The Supreme Court in its decision dated July 7, 1971 No. 294 K / Sip / 1971 requires "That the lawsuit must be filed by people who have legal interests". [7]

\section{B. The consequences of an obscure or obscure lawsuit (Obscuur Libel)}

The plaintiff's claim is declared rejected or declared unacceptable, then the concerned will not accept such a decision, because the decision does not satisfy what he wants from the claim as stated in the lawsuit.

If the plaintiff's lawsuit is declared unclear or obscure (obscuur libel) so that the lawsuit cannot be accepted, of course the person concerned is not silent in accepting the Judge's Decision without using legal means to refute the Judge's Decision. However, the problem now is if the Judge's Decision which states the lawsuit is unclear or obscure (obscuur libel) so that the lawsuit cannot be accepted can only file an appeal if they do not accept the decision, then what measures can the plaintiff make if the lawsuit is declared unclear or obscure. (obscuur libel) so that the lawsuit cannot be accepted. This problem is a legal consequence that arises against the plaintiff if the lawsuit is unclear or obscure (obscuur libel) so that the lawsuit cannot be accepted.

There are two alternatives that can be made by the plaintiff if his claim by the judge is deemed unacceptable. The two alternative efforts are:

1. File a new lawsuit

This first alternative is an advantage over the decision which states that the lawsuit cannot be accepted when compared to the lawsuit which is declared rejected. It is said to be excess, because if in a lawsuit that is declared rejected by the plaintiff, it can only make an appeal against the judge's decision (if it does not accept the verdict) it turns out that in a lawsuit which is declared unacceptable the plaintiff is still possible to file a new lawsuit in addition to other alternatives, 
namely filing an appeal. So the plaintiff has two choices, whether to file a new lawsuit or file an appeal. To choose it is up to the plaintiff which in his judgment is more favorable. The two alternatives do have their own advantages and disadvantages.

If the plaintiff uses the first alternative, namely filing a new lawsuit, then there are some losses arising on the part of the plaintiff, namely the Plaintiff must bother to make a new lawsuit to replace the old lawsuit, but with the new lawsuit it is hoped that the lawsuit will fulfill the formal requirements of the lawsuit so that the lawsuit will be after re-examined has no more deficiencies so that the lawsuit.

The second alternative is taken by the plaintiff, so that the benefit obtained by the plaintiff, namely the plaintiff, does not bother to compile / make a new lawsuit replacing the old lawsuit. This also means that the plaintiff does not incur additional costs as the case is processed faster by a higher court.

If the appellate judge (High Court) is of the opinion that the plaintiff's claim has met the formal requirements, then the appellate judge has been able to consider and decide the main case of the case, whether the plaintiff's claim can be granted or not. However, if the Judge of Appeal has the same opinion as the first judge. Then the plaintiff's claim will still be declared unacceptable.

If the appellate judge still states that the lawsuit is unacceptable, then the plaintiff can also choose one of two alternatives, namely to submit an appeal or accept the decision of the appellate judge to file a new lawsuit again. So even though the examination of the case has reached the appeal level, the plaintiff is still given the freedom to choose whether to file a new lawsuit or to declare an appeal to the Supreme Court of the Republic of Indonesia. Such a thing could happen, because most likely the plaintiff only realized and believed that his lawsuit had flaws after reading the appeals Judge's considerations which were granted by the Judge. However, it is not impossible that this new lawsuit also has shortcomings that make the lawsuit unacceptable. However, according to usually such things rarely occur, because the plaintiff has known where the shortcomings of his first lawsuit caused his lawsuit to be declared unacceptable, of course these deficiencies have been corrected when filing a new lawsuit.

In addition to these losses, another loss is that the plaintiff will incur additional costs, because to file a new lawsuit, the plaintiff must pay fees as when filed the first lawsuit. A new lawsuit is not merely an amendment which is considered to be an integral part of the new lawsuit, it is an independent case, with a separate Register Number and separate fees.

2. File an appeal

If the plaintiff does not want to file a new lawsuit, the plaintiff can file an appeal against the judge's actions that stated his lawsuit (Niet Onvan kelijkver klaard). This is possible because according to the plaintiff's judgment that his lawsuit has no shortcomings, but it is the Judge who is wrong to give considerations which result in his claim being unacceptable.

If later submitting an appeal to the Supreme Court, it is likely that the verdict will be the same, namely that the lawsuit will still be declared unacceptable. With such forecasts, the plaintiff finally drew the conclusion to file a new lawsuit. However, there are also times when the plaintiff remains in his belief that his lawsuit is complete and then does not accept the appeal judge's decision and then submits an appeal to the Supreme Court of the Republic of Indonesia.

In such a situation, in addition to the fact that the plaintiff did not incur more costs, the process of examining the case was completed faster than if he filed a new lawsuit. However, on the other hand, the plaintiff may suffer the greatest loss if the Supreme Court Judge believes that the plaintiff is incomplete and therefore decides that the lawsuit is declared unacceptable while affirming the decision of the Court of First Instance. The plaintiff must wait for a definite decision on his lawsuit. 
If the first examination process from the district court to the Supreme Court has taken five years, then at least the time that must be spent is waiting for the final decision on the new lawsuit that has been submitted, because in fact the process of settlement of cases from the district court to the Supreme Court is at least took five years, often longer than that. And usually in civil cases, regardless of who loses and who wins between the plaintiff and the defendant, what is clear is that the party who feels himself defeated always submits an appeal / cassation to a higher court. That means a civil case often has to wait for the final decision from the Supreme Court.

\section{CONCLUSION}

(1) The reason the judge stated that a lawsuit was unclear or obscure (obscuur libel) were nine factors that caused the claim submitted by the plaintiff to be unacceptable. The nine factors are: (a) The identity of the parties (Plaintiff and Defendant). (b) The object of the lawsuit being litigated is unclear. (c) Petitum lawsuit exceeds the claim posita. (d) Power of attorney does not meet the requirements. (e) The lawsuit is filed by an underage / incapable person. (f) Claims are not filed on time. (g) Incomplete parties. (h) The court is not competent to hear the claim that is submitted. (i) The grounds of the plaintiff's rights are not clear. (2) As a result of a lawsuit is unclear or obscure (obscuur libel), then the person concerned does not accept such a decision, because the decision does not give satisfaction to what he wants from the claim as stated in the lawsuit. Because the verdict cannot be accepted in practice in the District Court based on the consideration that the plaintiff's claim is unacceptable, in fact it is a consideration regarding the subject matter of the case, namely whether the plaintiff is the owner or entitled to the suspect land, it is more appropriate to declare the claim rejected. Therefore, the plaintiff's unclear rights to the object of the lawsuit in dispute are not appropriate to be used as legal considerations to declare the claim unacceptable.

\section{REFERENCES}

[1]. Bambang Sunggono. 2003. Metode Penelitian Hukum, PT. Raja Grafindo Perkasa: Jakarta, h, 36

[2].K. Wantjik Saleh, 1991. Hukum Acara Perdata Rbg/HIR, Ghalia Indonesia: Jakarta

[3]. Abdul Manan. 2005. Penerapan Hukum Acara Perdata di Lingkungan Peradilan Agama. Prenada media: Jakarta. h, 299

[4]. Darwan Prinst. 2002. Strategi Menyusundan Menangani Gugatan Perdata. Citra Aditya Bhakti: Bandung. h, 203-204

[5].R. Subekti. 2002. Hukum Acara Perdata. Bina Cipta: Bandung. h, 19

[6]. Tresna. 1990. Komentar HIR. Pradnya Paramita: Jakarta, h, 27

[7]. Sudikno Mertokusumo. 2002. Hukum Acara Perdata Indonesia, Liberty: Yogyakarta. h, 33. 